A 101

\title{
感圧塗料による高速列車の後尾部流れの可視化
}

小寺 健幸, 山下 太郎, 浅井 圭介, 永井 大樹 (東北大学)，森田 潔(日立製作所）

\section{Pressure-Sensitive Paint Measurement of Flow around High-Speed Trains with Different Tail Shapes}

\author{
Takeyuki KODERA, Keisuke ASAI, Hiroki NAGAI, Taro YAMASHITA and Kiyoshi MORITA
}

\begin{abstract}
Optimizing the performance and increasing the comfort of high-speed trains require the knowledge of aerodynamic effects of a train shape. One of the most critical problems is a compression wave caused by a train entering a tunnel. This noise mainly depends on the cross-sectional area distribution of a train nose. On the other hand, the aerodynamic drag, the stability for side wind, and the low-frequency vibration are attributed to tail shapes. In this study, we studied the effects of train tail shapes on the flow field experimentally. Two models having the same cross-sectional area distribution but with different tail shapes were tested in a low-speed wind tunnel. To analysis the flow field around the model, we used pressure sensitive paint and oil flow techniques. As a result, we could identify the effects of tail shapes for pressure drag and cross wind stability.
\end{abstract}

Keywords: High speed train, Tail shapes, Pressure-Sensitive Paint, Oil flow.

\section{1. 緒 論}

近年、新幹線の速度向上に伴い空気力学上の様々な問 題が重要視されている。代表的なものとして、空気抵抗 やトンネル微気圧、横風安定性といったことがあげられ る。最新の新幹線の形状はこれらを考慮して決められて いる。

中でもトンネル走行時に発生する微気圧波は、近隣一 の騒音や振動の原因となるため大きな問題となっていた。 この微気圧波の発生は先頭車両形状に依存する1。この 影響を軽減するため、現在では最適な先頭車両の断面積 分布が求められており、新幹線にも適用されている。

しかし一方では、抵抗や横風安定性には後尾部車両の 形状が大きく影響することが知られている。一般的に、 新幹線の先頭車両と後尾部車両は同一形状であるので、 微気圧波の低減を考慮に入れた断面積分布が後尾部車両 にも反映されることになる。つまり、この制約条件内で 後尾部車両に働く抵抗や横風に対する影響が少なくなる ように、車両形状を決めることが設計上の重要な課題と なっている2。

このような課題を解決する上で、車体面上に働く力(表 面圧力)を計測することは重要である。

そこで本研究では、近年発達著しい感圧塗料 (Pressure-Sensitive Paint, PSP) 計測技術を用いて同 一断面積分布で後尾部形状の異なる二種類の車体につい て風洞実験を行った。その結果から、形状差異が車体に
どのような影響を及ぼすかを調べた。

\section{2. 計測方法}

2.1 感圧塗料 (Pressure-Sensitive Paint, PSP)

PSP は、色素と高分子からなる分子センサである。こ れを用いる利点としては、圧力測定は従来の静圧孔のよ うな点計測ではなく面計測ができる、また、非接触計測 なので流れ場を乱さない等がある。

感圧鉣料（PSP）の原理を以下にまとめる。PSP で用 いられる色素は、励起光が照射されるとエネルギーを与 えられ、より高いエネルギー準位に励起されるが、その エネルギーを蛍光や燐光といった発光で失い、基底状態 に戻る。一方、周りの酸素分子と反応しても励起エネル ギーは失われ、この場合、発光は生じない。これを酸素 消光と言う。

酸素濃度は分圧に比例し、空気中の酸素分圧は常に静 圧の $21 \%$ 等しいので、この性質により局所的な酸素濃 度とその点の圧力が対応付けられる。一般に、発光強度 I と圧力 P は以下の Stern-Volmer 関倸式で表される。

$$
\frac{I_{r e f}}{I}=A(T)+B(T) \frac{P}{P_{r e f}}
$$

ここで $P_{\text {refl }}$ 基準状態の圧力（既知の圧力、本実験では 大気圧)、 $I_{r e r}$ 基準状態の発光強度 ( $P_{r e f}$ での発光強度)、 $て$ は温度である。この関係より、PSPを塗布した模型表面 に励起光を照射した際のPSPの発光強度を計測すること 
で表面圧力を求めることができる。このときの計測模式 図をFig.1に示す。

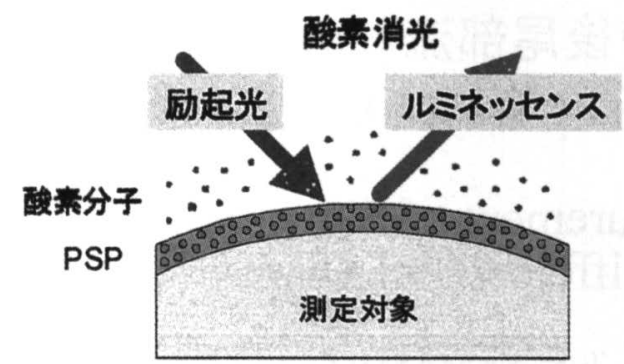

Fig. 1 Schematic of PSP measurement

本実験では、PSP として、ISSI 社 (Innovative Scientific Solutions. Inc.) の BF405 を用いた。これは、励起波長が $405[\mathrm{~nm}]$ であり、発光波長は、感圧色素が $650[\mathrm{~nm}]$ 、基準 色素が $550[\mathrm{~nm}]$ である。模型には、発光強度を強くし SN 比を高めるために、最初に白色の下地塗料を、さらには 温度による発光強度の変化を抑えるために Base Coat を 塗布し、その上から PSP をスプレーで塗装した。

\subsection{Oil Flow}

Oil Flow とは模型表面に油と顔料の混合物を塗布し、 流れにさらすことで流体のせん断力によって現れる縞・ 筋などの模様から、物体表面極近傍付近の流れの方向を 調べる方法である。

今回の実験では模型全面に混合物を塗布し、流れの方 向を調べた。用いた混合物は油としてシリコン油 $50 \mathrm{ml} 、$ 顔料に酸化チタン $25 \mathrm{~g}$ 、表面活性にオレイン酸 $1.2 \mathrm{ml}$ 、 適度な粘性を持たせるために油とは別に流動パラフィン $1.1 \mathrm{ml}$ を用いた。

なお、可視化するにあたっては混合液の液垂れによる 干渉を防ぐために上面、側面とも先頭部、中間部、後尾 部とそれぞれにわけて実験を行った。

\section{3. 実験模型}

今回の実験で用いた模型を Fig. 2 に示す。これらの模 型は、長さ $292 \mathrm{~mm}$ 、高さ $27.1 \mathrm{~mm}$ 、幅 $28.2 \mathrm{~mm}$ と共に 同じである。ただし先頭部・後尾部車両の形状は、断面 積分布は等しいが、形状はそれぞれ異なるもの(模型 1 、 模型 2) を使用した。模型 1 の特徽は幅が全長を通して 一定であり、高さのみが変化するくさび形状である。一 方、模型 2 は模型中間部の高さと横の比を基準とし、先 頭部すべての断面において基準と同じ比になる形状であ る。二つの模型の模式図を Fig.3 に示す。なお両模型に はPSP の温度補正のため後尾部付近に熱電対を 7 点、 PSP 結果との比較のため静圧孔を 8 点設置した。図中で はそれぞれ中空青丸、緑丸で示した。

模型はまず、二つの足に設けたネジ穴を用いてアクリ ル円板 $(\phi=250 \mathrm{~mm})$ に固定し、さらにその円板ごと、 風洞測定部に設置した地面版に固定した。このアクリル

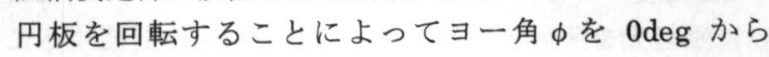

$90 \mathrm{deg}$ まで $5 \mathrm{deg}$ 間隔で変更することができ、横風を受 けた状態を模擬することができる。今回の実験はヨー角 $\phi=0 、 30 \mathrm{deg}$ で実験を行った。

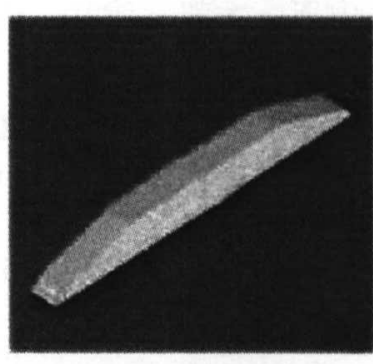

(a) model 1

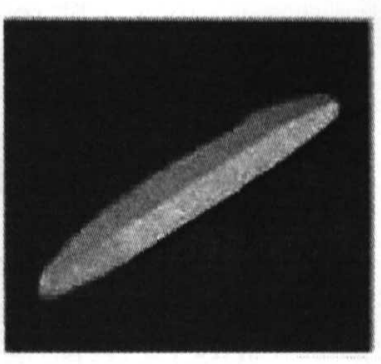

(b) model 2
Fig. 2 Overview of model

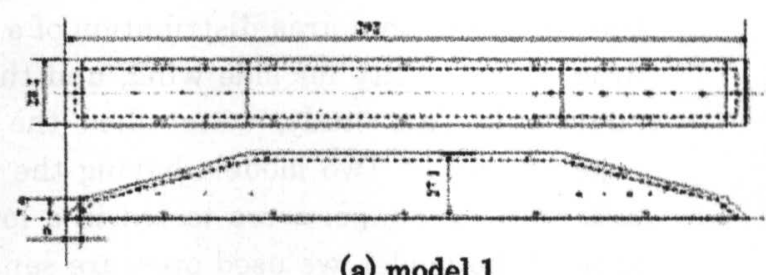

(a) model 1

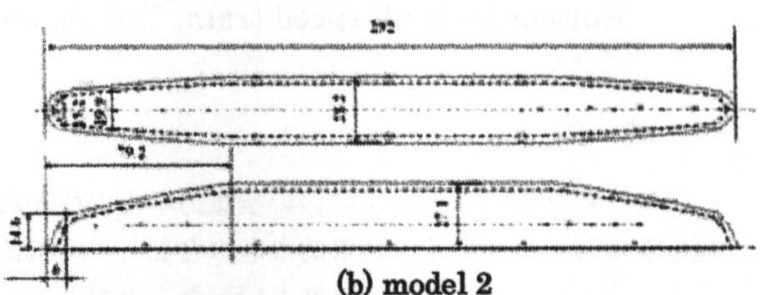

(b) model 2

Fig. 3 Schematic Illustration of model

\section{4. 実験装置}

今回の実験に用いた風洞は東北大学基礎実験用低速風 洞(T-BART) ${ }^{3)}$ である。計測セットアップの概略をFig.4に 示す。

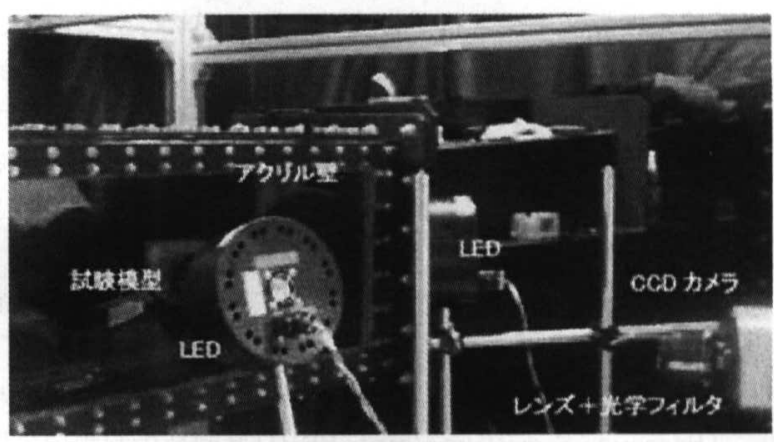

Fig. 4 Experimental setup for PSP measurement 
この風洞は大気吸い込み型であり、通風による温度上 昇が比較的小さいため PSP を用いた低速領域での実験 に適している。今回の流速は $50 \mathrm{~m} / \mathrm{s}$ で一定とした。測定 部は密閉型であり、寸法は $300 \mathrm{~mm} \times 300 \mathrm{~mm} \times 760 \mathrm{~mm}$ で ある。測定部の形状が直方体で測定面が 4 面存在する。 その測定壁としてアクリル壁を使用しているので上下左 右からの光学計測が可能である。

PSP 計測では使用塗料 BF405に対応して励起光に UV LED(中心波長 $395 \mathrm{~nm}$ ) を 2 基、光検出器として冷却 CCD カメラ(16bit,1024×1024pixels)を用いた。CCD カ メラには、感圧色素の発光の中心波長 $650 \mathrm{~nm}$ だけを検 出できるよう $650 \pm 20 \mathrm{~nm}$ のバンドパスフィルタを装備 した。

\section{5. 結果および考察}

\section{$5.1 \exists$ 角 $\phi=0 \mathrm{deg}$ の場合}

まず、PSPによる圧力分布の計測結果をFig.5 に示す。 図は上面から模型後半部分のみを捉えた画像であり、圧 力係数 $C_{p}$ に換算した值で表示してある。流れの方向は左 から右である。この結果からわかることは、両模型とも 後尾部開始点付近に負圧領域が存在することである。こ れは模型 1 のほうが大きい。さらには、模型 1 のみ後尾 部稜線に沿い負圧領域が発達している。これは模型 2 に は見られない。

次に後尾部の Oil Flow の可視化結果を Fig.6 示し、PSP の結果と対比する。両模型とも、後尾部開始点から少し 後方に向かったところに付着の模様が見られる。これは 中間部からの流れが後尾部開始点付近で剥離し、再び付 着したことで生じたと考えられる。Fig.5 の PSP の結果 に見られた負圧領域は、この剥離により生じたものと考 えられる。また Oil Flow の結果から、模型 1 では稜線か ら中心線に向かい発達する剥離の模様が存在することが わかる。これは模型 2 には見られない。この剥離の模様 は稜線からと、中心線からの流れがぶつかることにより 生じ、さらに発達している。Fig.5 の PSP の結果ではこ の付近が負圧領域となっていることからも、この部分に は縦渦が存在すると考えられる。

以上から $\phi=0 \mathrm{deg}$ の時、中間部からの流れが剥離する ことにより生じる負圧領域は模型 1 の方が大きく、また 縦渦の存在により後尾部上面に生じる負圧領域は模型 1 の方が大きいことになる。以上を総合すると空気抵抗が 大きいと考えられる。

\section{$5.2 \exists$ 角 $\phi=30 \mathrm{deg}$ の場合}

次にヨー角 $\phi=30 \mathrm{deg}$ の場合の PSP の結果を Fig.7 に 示す。この結果からまず、両模型とも中間部では風上側 から風下側に向かって発達する大規模な負圧領域が存在 することがわかる。一方、後尾部では中間部とは逆に風 下側から風上側に向かい負圧領域が発達していることが わかる。

これらの結果をFig.8、9に示したOil Flowの結果と対

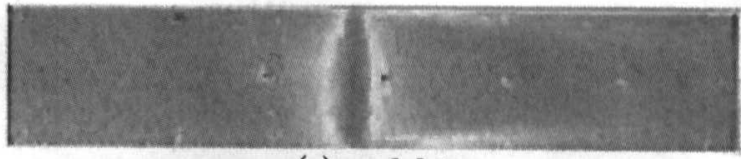

(a) model 1

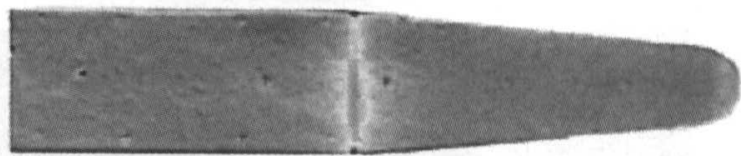

(b) model 2

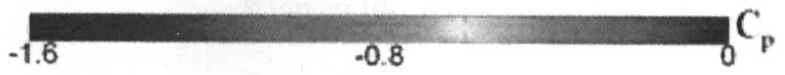

Fig. 5 Pressure distribution of upper surface

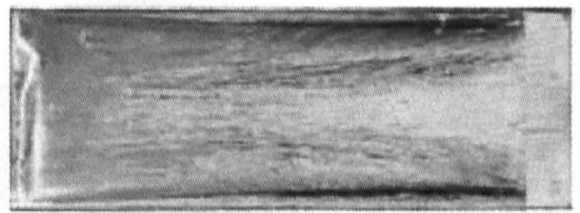

(a) model 1

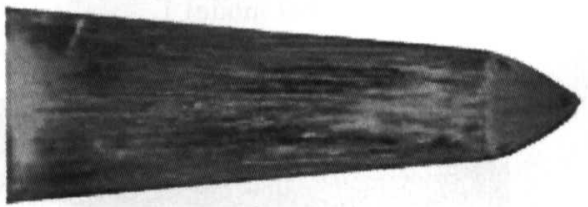

(b) model 2

Fig. 6 Oil flow visualization of upper surface

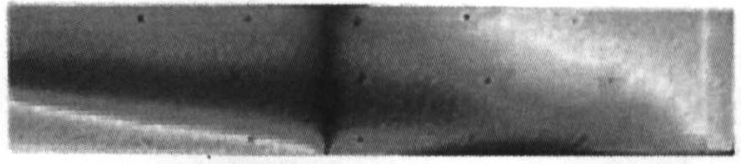

(a) model 1

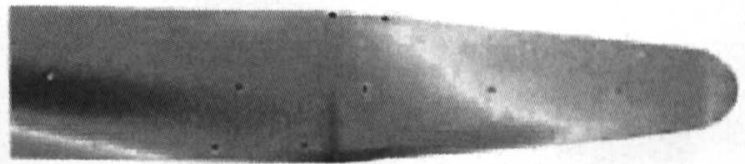

(b) model 2

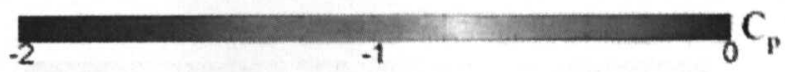

Fig.7 Pressure distribution of upper surface

比して考える。

まず、Fig.8の結果から両模型とも左上から斜めに剥離 の模様、さらにその下方に付着の模様が発達しているの が見られる。これは風上側からの流れが稜線で剥離した 流れが付着し、さらに風上側に向かった後に剥離したも のと考えられる。つまりこれは大規模な剥離渦が発達し ているものと考えられる。PSPに見られた負圧領域はこ の剥離渦に対応していると考えられる。このような流れ は杉浦3)が行った実験にも見られる。Fig.9の結果では、 


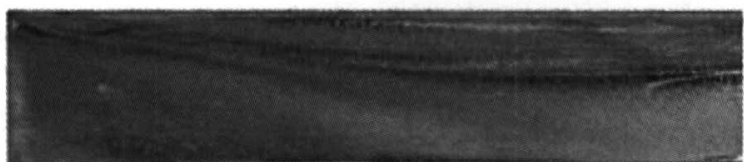

(a) model 1

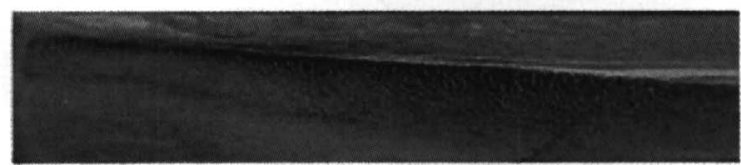

(b) model 2

Fig. 8 Oil flow visualization of upper surface in the middle of model

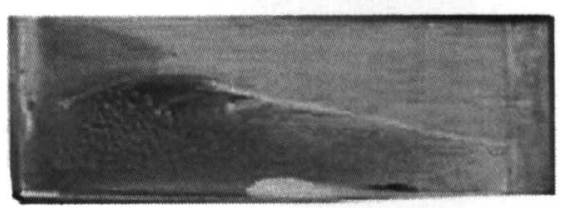

(a) model 1

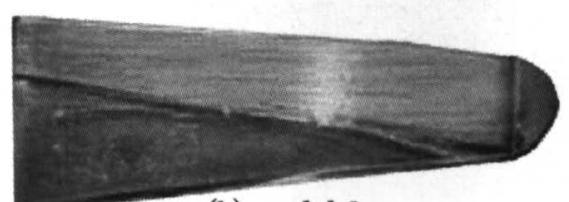

(b) model 2

Fig. 9 Oil flow visualization of upper surface

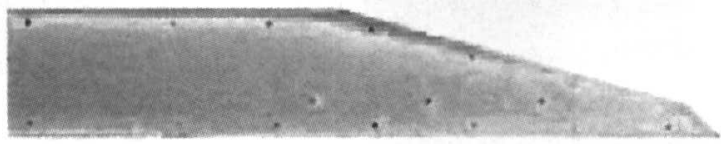

(a) model 1

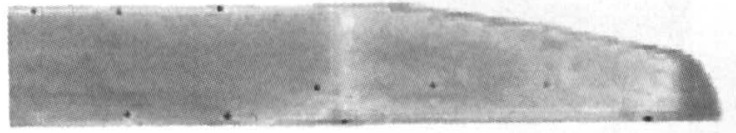

(b) model 2

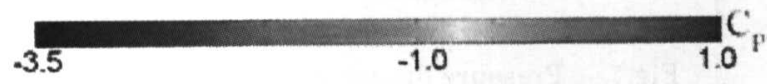

Fig. 10 Pressure distribution of side surface of windward

PSP に見られた負圧領域に対応したところに、風下側か ら風上側に向かう流れが存在しているのがわかる。これ は中間部に見られた剥離渦の発達がついには模型上面の 前面を覆い、さらには側面の流れと干涉し風上側に巻き 上げられたのではないかと考えられる。そこでの複雑な 流れにより渦が発生し、PSPに見られる風上に向かう負 圧領域が発生していると考えられる。

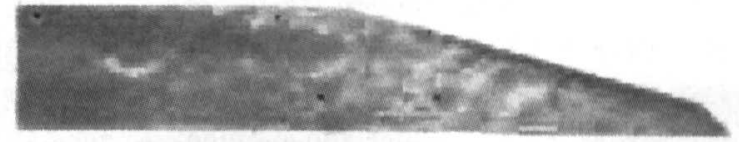

(a) model 1

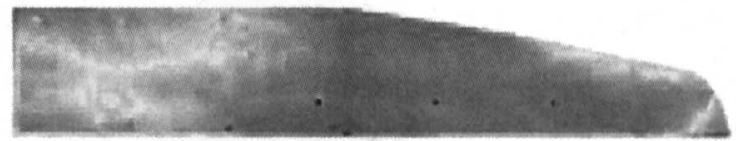

(b) model 2

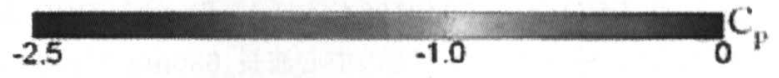

Fig. 11 Pressure distribution of side surface of leeward

次に側面についての考察を行う。風上側と風下側の側 面の圧力分布を比べることにより、働くヨーイングモー メントの大小を比較し、横風安定性を評価できる。まず 風上側面の PSP の結果を Fig.10 に示す。結果から分か るように、風上側面の圧力係数は約 -0.3 で同じであり、 ほぼ一様であるといえる。次に風下側面のPSP の結果を Fig.11 に示す。模型 1 の後尾部風下側面では圧力係数が -1.0 程度でほぼ一定なのに対して、模型 2 の後尾部風下 側面では圧力係数が-1.3 と大きく違う。そのため、風上 側面との圧力差は模型 2 の方が大きいことになり、より 横風安定性が悪いと考えられる。また、Fig.7 に見られ た風上側に向かい発達する負圧領域に対応した部分が側 面からも捉えられているのがわかる。

\section{6. 結論}

1. PSP を用い $\phi=0 、 30 \mathrm{deg}$ の模型まわりの流れ場の 圧力分布を捉えた。また、Oil Flowにより圧力と渦 や剥離との相関を明らかにした。

2. 同一断面積変化の模型でも, 3 次元形状の差異によ り, 流れ場が大きく異なることが確認できた。

\section{参 考 文 献}

1）井門敦志、飯田雅宣、前田達夫、列車先頭部 - 後尾部形状 最適化のための風洞試験、鉄道総研報告、Vol. 7, No. 7, 93. 7

2）小澤智、高速列車の空気力学的諸問題、ながれ、vol. 21 No. 4 P346-P353 (2002)

3）杉浦光、車体周り流れと横風特性に関する研究、平成 18 年度東北大学大学院修士学位論文, (2007). 